\title{
Forest Management Systems in Western Hill Nepal: A Study of Mahabharat Tract, Arghakhanchi District
}

\author{
Lekha Nath Bhattarai
}

\begin{abstract}
This article intends to examine the dimensions of existing forest management systems in the western hill of Nepal on the basis of field survey conducted in the Mahabharat tract of Arghakhanchi District. The study suggests that there is a simultaneous existence of three regimes of forest administration and management in the study area, namely state controlled system, privately owned system and the community management system. Neither the forests are protected nor any initiatives of management as such found to have launched under state controlled system. However, the privately owned forests and pastures found to have managed better and so the community managed forests tracts. Although the community forests in area and intensity seems to be still in infancy the perception of the locals was found highly enthusiastic towards it and it is found directly related to the degree of scarcity of forest products. The assessment of some of the successful community forests entails that the emerging model of community forest is getting indispensable and right option for the better management of remaining forests despite some of the impediments posed due to heterogeneity within the communities of the users, the uneven distribution of the forests across the village settlements, undefined boundaries and tedious official procedures for handing over.
\end{abstract}

THE FOREST IS THE Most crucial environmental resource to the rural masses in Nepal. But Nepalese forest is at a great stake in the face of growing population (human as well as livestock) pressure, unsustainable harvesting of forest resources and unfavorable forest management practices as well as due to the lack of alternative options and opportunities. There exists apparent linkage between forests and existing subsistence economy based on agro-pastoral activities, which is a mainstay of almost all the households in rural areas in Nepal, the use of forest resources neither can be reduced nor avoided without shifting the existing rural economic activity (Bhattarai 2004, Thapa and Weber 1990, Bajracharya 1983). The current challenge is, therefore, how to halt the degradation without disturbing the livelihood of the people. So, the best option is to conserve the existing forests adopting an appropriate management mechanism.

There are contrasting theoretical positions regarding appropriateness of the particular system (state control, privatization solution and community models) and also contradictory empirical findings of the success or failure of the different modes of management associated with them, including forest management (Agarawal 2001, Ostrom 1990, Baland and Platteau 1996, Hardin 1967). Although the local control over natural resources is believed to be a win-win solution for environment and development, the empirical evidences regarding the economic impact of the same have not been much optimistic, especially with respect environmental justice (Adhikari et al. 2004, Adhikari 2003). Nevertheless, a consensus is emerging in favor of the local level management by the users' themselves (Bhattarai 2004, Baral 2002, Ostrom 1990). 


\section{Objectives}

The main objective of this paper is to examine the existing forest management systems in western Hills Nepal. However, the specific objectives are: to analyze the different forest management practices, identify the people's perception towards particular mode of management and to assess the status and problems of existing community management initiatives.

\section{Data and Methods of Analysis}

The required data and information were collected from the field survey in Mahabharat Tract of Arghakhanchi district. Information used in this article are generally qualitative in nature based on the field observation, household survey and informal discussion with key informants conducted in March-June, 2002, during author's doctoral research. Out of 13 Village Development Committees (VDC) located in the study area, 20 wards of 10 VDCs were selected for the detailed study. For the purpose of household survey, however, 15 percent of the households were selected randomly from the list of total households of the purposively selected two wards each from 10 VDCs. Secondary data obtained from the VDC offices were also used wherever applicable. The analysis is based on mainly descriptive and tabular presentation. However, Chi-square test has been used to test whether people's perception on particular mode of management differs significantly between two regions of the study area.

\section{Analysis and Discussion}

\subsection{Existing Forest Management Systems and Practices in the Study Area}

There were broadly two forms of forest management regime in the study area- public and private, based on ownership of the forestland. Public forest was under the state ownership and control while private forests and pastureland, locally called as Kharbari, was under individual ownership. The public forest can be further classified into two types: controlled by the government administration and managed by the community of the immediate users. Within community forest also there were two forms of management: informal and formal (Chart 1). Let us discuss this typology of forest management in details.

Private Forests and Pastures: As mentioned earlier, there was a large area of forest and pastureland under private ownership in the study area. The relatively better-off households in the area had been found kept some area of forest and pasture land as the Kharbari. However, this form of land holding has not been formally recognized as forests land by the state legal framework. It falls under farmland in Chahar category. Apart form this, a large number of trees are grown around the cultivable lands, which also supplement the fodder/ litter, fuel wood and timber requirement of the households. The private forest and pastures found to have covered about one third of the total forest area. Moreover, about one third of the fuel wood and about two third of the fodder/litter need were fulfilled by this source. Similarly, a considerable portion of household timber need also reported to be collected from this source. That is why this form of forest and pasture have been playing significant role in the household use of the forest resources, which cannot be ignored while examining the existing forest management system. 
The forest and pasture patches under private ownership found well to have managed by the owner. Access to forest resources is allowed to the owner households only. Any attempts of outsider's offences are panalized under the existing laws. They routinely cut the undergrowth grass, trim the unwanted branches, remove the thorny bushes, lope the tree branches of fodder trees, and cut the old or dried trees for fuel wood and timber use. The owner themselves take care of the area, routinely invest for fencing and implant trees and other grass species. If we look at the practices of harvesting resources from private forest and pastures, no single unfriendly method was on sight. Interestingly, the same people generally used to harvest the resources from the public forests adopting relatively unfriendly techniques. It may be due to its open access situation, where the property right is not clearly defined and people feel 'public forest means nobody's forest'. In this sense the Property Right School's proposition seems to be justified. However, in regulated common property regime, such as community forest the same kind of practices could hardly be found.

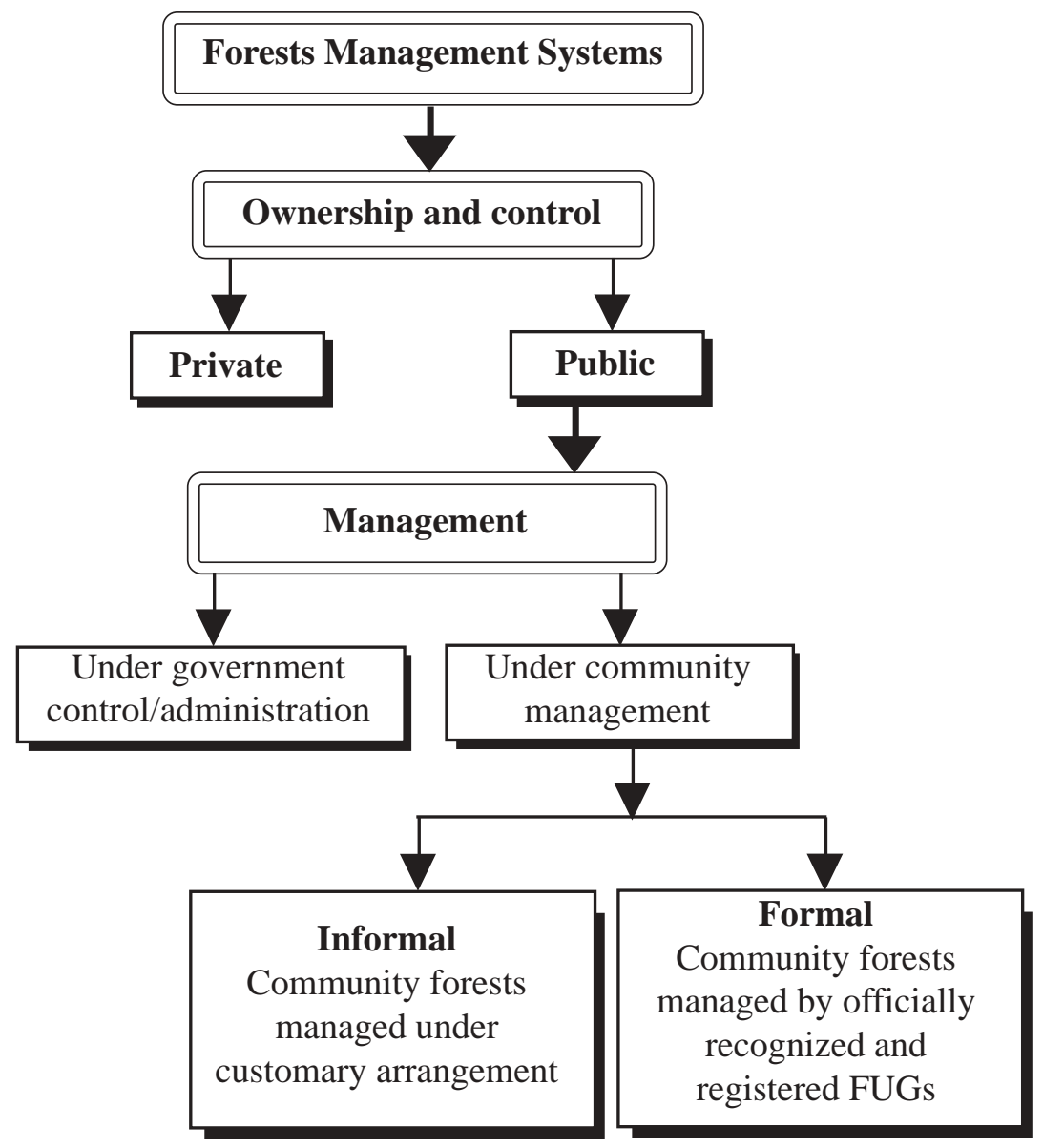

Fig. 1: Typology of Existing Forest Management System in the Study Area

Public Forest under State Control and Administration: In the study area, public forest under the state control and administration constitutes the dominant position. It is evident 
from Table 1 that 62 percent (nearly 11300 hectors) of the forest area was under this regime. The government officials were supposed to be taking care of all remaining forest tracts, which have yet to be handed over to the communities. These tracts include large areas of highly rich forests such as Sal forest of the Siwalik range and adjoining Mahabharat tract. So, the significance of this management regime cannot be underestimated.

The district forest office under forest department has sole authority over public forest for the control and management of the resources within the district boundary. For this purpose, eight range posts were functioning in the district. One range post had covered two to nine village development committee areas depending on the forest area. For each range post one ranger, one assistant and four forest guards had been posted. The study area falls under the four range posts, namely Dohote, Pawar, Pali and Sandhikharka. To coordinate and monitor the function of three-range posts (Pawar, Dohote and Dobata) one block level (locally called elaka) forest office had been in function in Thada with one forest officer and eight office assistants and helpers.

The responsibility of the district forest office is to coordinate all the forest management activities, including preparing and implementing district level projects and to protect public forests within the district boundary. The officials and guards of the field level range posts were said to have mainly concentrated to petrol the forest area regularly aiming to check the various offences. They basically took vigilances towards possible offences such as tree felling, timber logging, and forest area encroachment. They were entrusted authority to arrest offenders and to charge penalties and forward further for legal action. In serious cases, they can even shoot the offender as well.

Local residents had been extracting considerable amount of products and services from these forests since long. Those who do not possess forest and pasture land title were almost entirely depending on such public forest for fodder/litter, fuel wood, timber and other minor products. Even the landed-class also wants to extract resources from public forest whenever possible. People generally send their grazing animal to public forest. Interestingly, wherever there existed community arrangement in the nearby forest patches, their success were also found largely depend on the access of public forest. Because of the restriction posed in nearby forest, people were exploiting more from distant forests. It means the users had been enjoying almost open access situation in the public forest, despite the fact that people should have permit from forest office to use the resources. The permit system was largely limited to timber extraction in practice to some extent. Such permit provision also seemed to be unenforceable to the local users even to extract timber; it may have relevance to large-scale wood contractors. From these ground realities what can be perceived clearly is that the administrative arrangement was not working satisfactorily in the strict management sense of the term in the study area.

Community Management of Forest: Two variants of community management were found in the study area: informal and formal. As mentioned in previous section, a formal community management refers to the system of community forestry, under which the forest areas were formally handed over to the forest users' groups (FUGs) by the forest authority. Formally instituted FUGs take charge of all the matters related to community forests including benefit sharing, devising rules of access, and all conservation and management activities. Informal community management of forest refers de facto type of customary system, which 
has been traditionally regarded as community forest by the people even though such forests are not formally handed over to communities concerned.

A special type in this category of forest is popularly known as Raniban (literal meaning queen's forest). It is generally located around the source of drinking water along the settlements. These forests were found well maintained. Similarly, in some villages, some forest areas around their vicinity were found protected and managed by the villagers themselves. The villagers manage these forest patches without getting any formal legal sanction from the forest authority even though the ownership right has been rest on the state. These forests may be called ward-managed forest. Generally, the ward representatives look after it without having any formal special forest committees. The villagers themselves devise their own rules regarding access, harvest time, graduated sanction for offences. Nobody is allowed to cut down the trees and branches of trees although no restriction are posed to collect dead branches, grass, dried leaf litter, roots, fruits and also for grazing. Outsiders are strictly excluded for using these forest patches.

Formal type of community management system initiated in 1993 in the Arghakhanchi district, immediately after the Forest Act 1993 came into effect. According to the District Forest Office, by the end of March 2002, a total area (including the study area) of 8775.85 ha forests had already been officially handed over to the 231 FUGs, covering 23,569 households of users benefiting 139,661 populations all over the district. These data clearly reveal the fact that community forestry was at the nascent stage in the district.

\section{Table 1: Forest and Pasture under Different Management Systems in the Study Area} by VDCs

\begin{tabular}{|c|c|c|c|c|c|c|c|c|}
\hline \multirow[b]{2}{*}{ VDCs } & \multicolumn{5}{|c|}{$\begin{array}{c}\text { Forest and Pasture Area Under Different } \\
\text { Management Regime (Area in Ha) }\end{array}$} & \multicolumn{3}{|c|}{$\begin{array}{l}\text { Percentage of Forest/ } \\
\text { Pasture Area Under }\end{array}$} \\
\hline & State * & $\begin{array}{l}\text { Comm- } \\
\text { unity* }\end{array}$ & $\begin{array}{c}\text { Total } \\
\text { Public } \\
\text { Forest } \\
(4=2+3) \\
\end{array}$ & $\begin{array}{c}\text { Private } \\
\text { Forest/ } \\
\text { Past- } \\
\text { ure** }\end{array}$ & $\begin{array}{c}\text { Total } \\
\text { Forest/ } \\
\text { Pastures } \\
(6=4+5)\end{array}$ & State & $\begin{array}{l}\text { Comm- } \\
\text { unity }\end{array}$ & Private \\
\hline (1) & (2) & (3) & (4) & (5) & (6) & (7) & (8) & (9) \\
\hline Dhanachaur & 718.3 & 105.0 & 823.3 & 499.6 & 1322.9 & 54.3 & 7.9 & 37.8 \\
\hline Dhatibang & 843.8 & 175.0 & 1018.8 & 284.6 & 1303.4 & 64.7 & 13.4 & 13.9 \\
\hline Dhikura & 682.4 & 138.6 & 821.0 & 647.8 & 1468.8 & 46.5 & 9.4 & 44.1 \\
\hline Jukena & 2336.3 & 0.0 & 2336.3 & 1144.0 & 3480.2 & 67.1 & 0.0 & 32.9 \\
\hline Khanchikot & 673.6 & 173.3 & 846.8 & 474.0 & 1320.8 & 51.0 & 13.1 & 36 \\
\hline Maidan & 1522.3 & 158.4 & 1680.8 & 721.6 & 2402.4 & 63.4 & 6.6 & 30.3 \\
\hline Patauti & 282.8 & 310.9 & 593.8 & 323.0 & 916.8 & 30.9 & 33.9 & 35.2 \\
\hline Pokharathok & 818.3 & 119.3 & 937.5 & 214.0 & 1151.5 & 71.1 & 10.4 & 18.6 \\
\hline Sitapur & 1029.0 & 443.2 & 1472.3 & 619.9 & 2092.2 & 49.2 & 21.2 & 29.6 \\
\hline Subarnakhal & 1635.5 & 2.0 & 1637.5 & 229.1 & 1866.6 & 87.6 & 0.1 & 12.3 \\
\hline Total & 10542.1 & 1625.7 & 12167.8 & 5157.7 & 17325.5 & 60.8 & 9.4 & 28.6 \\
\hline Average & 1054.2 & 162.6 & 1216.8 & 515.8 & 1732.5 & 58.6 & 11.6 & 29.1 \\
\hline
\end{tabular}

Notes: 1. * Denote data obtained from District Forest Office, Arghakhanchi, 2001.

2. ** Estimated area based on average land holding reported by sample respondents which was computed multiplying the average holding under private forest and pasture category in the sample VDCs by number of households. 


\subsection{State of Community Forestry under FUG Management}

It is evident from the Table 1 that the forest under formal community regime had covered only 9.4 percent of the total forest area in the study area (including private forest and pasture). The state of CF in the study area is presented in Table 2. A total area of 1613.29 ha public forest had been handed over to the 38 FUGs, which was only 13.4 percent of the total public forest of the area. It seems to be fairly lower as compared to total district figures. Under the FUGs, 2823 households were participating to conserve and manage their forests. These users were empowered to devise rules of access and to plan and execute all the matter relating to conservation and management of their forest independently. The forest officers only supervise the activities of the FUGs and provide technical support in need. From the field study what came to be known that some other FUGs were under the process of getting their forests to their management.

Table 2 further reveals that community forestry was unevenly distributed over the study area in terms of number of CFs, and their coverage. In general, the VDCs located in northern belt of the Mahabharat tract have recorded higher number of CFs with high coverage as compared to the southern region. Within the northern region too, more intensive presence of CF was observed in Patauti and Dikura, followed by Khanchikot and Dhatibang.

Table 2: State Community Forestry (CF) in the Study Area by VDCs

\begin{tabular}{|c|c|c|c|c|c|c|c|c|}
\hline VDCs & $\begin{array}{l}\text { No } \\
\text { of } \\
\text { CF }\end{array}$ & $\begin{array}{c}\text { Wards } \\
\text { Having } \\
\text { CF }\end{array}$ & $\begin{array}{l}\text { Total } \\
\text { HHs }\end{array}$ & $\begin{array}{l}\text { No of } \\
\text { HH in } \\
\text { FUGs }\end{array}$ & $\begin{array}{l}\text { Percent } \\
\text { HH in } \\
\text { FUGs }\end{array}$ & $\begin{array}{l}\text { Total Area } \\
\text { Handed } \\
\text { over to } \\
\text { FUGs (ha) }\end{array}$ & $\begin{array}{l}\text { Potential } \\
\text { CF Area } \\
\text { (ha) }\end{array}$ & $\begin{array}{c}\text { Percent } \\
\text { of CF } \\
\text { Area }\end{array}$ \\
\hline Dhanachaur*** & 2 & $1,3,4,5$ & 757 & 291 & 38.4 & 105.0 & 823.3 & 12.8 \\
\hline Dhatibang* & 3 & $1,3,4$ & 432 & 160 & 37.0 & 175.0 & 1018.8 & 17.2 \\
\hline Dhikura* & 6 & $4,6,8,9$ & 909 & 602 & 66.2 & 138.6 & 821.0 & 16.9 \\
\hline Jukena** & 0 & - & 1235 & 0 & 0.0 & 0.0 & 2336.3 & 0.0 \\
\hline Khanchikot* & 3 & $1,3,9$ & 650 & 345 & 53.1 & 173.3 & 846.8 & 20.5 \\
\hline Maidan*** & 4 & 4,6 & 902 & 285 & 31.6 & 158.4 & 1680.8 & 9.4 \\
\hline Patauti*** & 7 & $2,3,4,6,7$ & 729 & 424 & 58.2 & 310.9 & 593.8 & 52.4 \\
\hline Pokharathok*** & 3 & $4,5,6$ & 736 & 198 & 26.9 & 119.3 & 938.5 & 12.7 \\
\hline Sitapur** & 9 & $1,2,3,4,5,6,7,8$ & 789 & 481 & 61.0 & 443.2 & 1472.3 & 30.1 \\
\hline Subarnakhal** & 1 & 3 & 585 & 37 & 6.3 & 2.0 & 1637.5 & 0.1 \\
\hline Total & 38 & - & 7724 & 2823 & 36.5 & 1625.7 & 12168.8 & 13.4 \\
\hline District total & 231 & & & 23569 & & 8775.85 & 37232.45 & 23.6 \\
\hline
\end{tabular}

Data source: District Forest Office, Arghakhanchi, March 2002.

Notes: *VDCs located in the northern region of the Mahabharat tract, ** that in the southern region and *** denotes that in both.

In Pokharathok, Maidan and Dhanachaur VDCs, community forestry was located in the wards and settlements located in the northern belt. In the southern belt, only in Sitapur, the institution of CF found to be intensive. This was an exception, however, because there was almost negligible presence of CF in other VDCs located in the southern region. It is due to the fact that in the south region, the degree of forest resource scarcity was relatively less than that of north, because large tracts of forest were still remained around the settlements 
in the region. Therefore, it can be concluded that the motivation towards CF is directly related to the degree of scarcity of the forest resources. This fact confirms the theoretical proposition that 'collective action for managing the commons would succeed only in the condition of acute scarcity of resources'.

The data from household survey also support the above-mentioned proposition. In the survey, respondents were asked to say their preference on particular mode of management. The cross tabulation of the response, presented in Table 3, depicts that majority of the respondents (61.6\%) expressed their preference for community forestry.

Table 3: Respondents' Preferences on Mode of Forest Management

\begin{tabular}{|c|c|c|c|c|c|c|}
\hline \multirow[t]{2}{*}{ Preferences } & \multicolumn{2}{|c|}{ North } & \multicolumn{2}{|c|}{ South } & \multicolumn{2}{|c|}{ Total } \\
\hline & $\mathbf{f}$ & Percent & $\mathbf{f}$ & Percent & $\mathbf{f}$ & Percent \\
\hline Undecided & 15 & 11.7 & 39 & 27.9 & 54 & 20.1 \\
\hline Government management & 5 & 3.9 & 26 & 18.6 & 31 & 11.6 \\
\hline Community management & 99 & 77.3 & 66 & 47.1 & 165 & 61.6 \\
\hline Private management & 9 & 7 & 9 & 6.4 & 18 & 6.7 \\
\hline Total & 128 & & 140 & & 268 & \\
\hline Chi-Square Test: & \multicolumn{2}{|c|}{ Value } & \multicolumn{2}{|c|}{ df } & \multicolumn{2}{|c|}{ Sig. } \\
\hline Pearson Chi-Square & \multicolumn{2}{|c|}{31.02} & \multicolumn{2}{|c|}{3} & \multicolumn{2}{|c|}{0.000} \\
\hline
\end{tabular}

' $f$ ' indicates frequency of respondent.

Data source: Field survey.

Even though the respondent's preference to community management appeared absolutely higher in both the regions, the differences of the same turned out to be statistically significant between the regions. Another interesting fact also emerged from the table that the frequency of undecided response is higher in the south (27.9\%) as compared to north $(11.7 \%)$, which indicates the lower awareness level regarding community rights among the respondents of the southern region.

\subsection{Performance of Community Forests}

Performance of the community forestry in the study area was uneven across the locations. It may be due to difference in resource availability across the location and socioeconomic diversity among the users' groups. Even though the formation of FUGs and other formalities in the process reported to be the same but the actual performance in practice found to have varied from one to another. Some FUGs were found actively participated in the management activities showing remarkable success in conservation of the forest whereas many others had shown negligible success for the same. For example, FUGs of ward 8 and 9 (joint) in Dhikura, ward 2 and 3 of Patauti, ward 4 in Pokharathok, ward 4 in Maidan, ward 4 in Dhatibang, and ward 6 in Sitapur had demonstrated remarkable success in managing tracts of forest under their management. The tracts of forest under these users' groups, although covered some small territory, observed to be well protected which could be clearly visible to their natural growth. However, the performance of other FUGs found to be negligibly across the study area.

From the informal discussion with respective FUGs members, school teachers and forest officials working in the area and my own observation of the CFs, the following characteristics of successful CFs were observed: 
i) The community forestry areas constituted well-defined boundary.

ii) The group composition of the FUGs comprised of relatively homogeneous in terms of socio-economic background of the members.

iii) Before FUGs took over the management and users' right from forest department, there was reported to have high pressure on the limited area of forest and consequently the condition of forest was extremely degraded.

iv) The forest patches were protected and showed excellent regeneration.

v) They had devised strict rules of access, harvesting and product sharing mechanism, and provisions of graduated sanctions for the possible offences and regular rotational watching system. In some FUGs even animal grazing had been also restricted.

vi) There existed good mutual understanding among the members. The dispute resolution mechanisms were well established.

vii) The leaderships were said to be undisputed and fair and the members had shown trust on them.

viii) All the activities regarding forest use and management and financial management were accomplished following democratic process and in transparent manner according to direction and decisions of the assembly of users.

ix) Majority of the members in FUGs reported to have possessed their own tract of forest and pastures or cultivable land with fodder tree, which support their daily need of fodder/ litter and partly the fuel wood. Similarly, the number of grazing animal was relatively less among them.

x) There were still some tracts of forests under the state control that were almost in open access condition. Even though these were located at some distance as compared to their own protected community forest which no doubt had been facilitating the users to extract forest resources in need.

xi) The members had expressed trust on the management regime and their attitude is highly enthusiastic to community forestry.

However, many of these characteristics were reported to be lacking in the FUGs having lesser or negligible success. In some cases, there existed a problem of well-defined boundary, due to which the neighboring villagers often claim their right over the tract that made the area disputed. In other cases, it was also reported that there was no mutual understanding among the members, people were reluctant to comply with the devised rule, and there was domination of the village elites in all decisions regarding the harvesting and the selling of forest products etc. The financial irregularities and mismanagement were also reported. What major problem perceived from these FUGs is that there was seriously lacking mutual understanding and trust in collective efforts and undisputed leadership, which are considered as driving forces for the 'collective action'.

\section{Conclusion And Policy Implications}

The forest management regimes observed in the study area was found followed the national pattern, i.e. three management regimes had been found functioning side by side. About 60 percent of the forest area was under government administration against 30 percent and 10 percent under private and users' group management respectively. Villagers were managing some tracts of public forest under customary community system without 


\section{The Journal of Nepalese Business Studies}

making any formal arrangement. The forests area under government control, although comprises the most valuable rich forest, was observed to be under great stake due to its virtually open access situation to the users. The forest administration seemed to have failed in managing the forests effectively. A few patches of community forests, informal as well as formal, had been observed to be regenerating, while a few others were found effectively managed by the users. The private tracts of forests and pasture were well protected and managed due to the existence of well-defined property rights and the owners were enjoying the power to exclude others from using resources. From this, what theoretical proposition seems to be confirmed that well-defined property rights (not necessarily privatization) over the natural resources is crucial for its effective management although it may results in exclusion of the poor. It is clearly confirmed from the historical fact that only the village elites had been benefited by the state induced appropriation of the public forests.

The performance of the community forests found to have varied across locations. In general, community forests in the north were found relatively effectively managed than that of south. Such differences observed to have associated with the relative scarcity of forests. Similarly, the performance also found varied across the communities. The relatively successful ones were characterized by well defined forest boundary, relatively homogeneous socio-economic composition of the users, well mutual understanding, well formulated rules of access, good leaderships etc. whereas the other less successful were found lacking most of these characteristics.

Any policy and programs intended towards conservation and management of forests should not ignore the socio-economic reality, especially the existing apparent socio-economic disparity among the users. It further implies that just changing the legislation to provide local autonomy to the users community may not be sufficient condition for better management, in the face of highly forest based existing farming system and acute state of poverty of the masses. It would, therefore, be important to support the local management initiatives providing affordable and viable alternatives to fuel wood, and other employment opportunities to reduce the existing forest based economic dependency.

\section{REFERENCES}

Adhikari, B. 2003. "Property Rights and Natural Resources: Socio-Economic Heterogeneity and Distributional Implications of Common Property Resource Management." Working Paper No. 1-03. Kathmandu: South Asian Network for Development and Environmental Economics (SANDEE).

Adhikari, B.; S. D. Falco and J. C. Lovett. 2004. "Household characteristics and forest Dependency: evidence from community property forest management in Nepal." Ecological Economics, vol.48, pp. 245-257.

Agarawal, A. 2001. "Common Property Institutions and Sustainable Governance of Resources." World Development, vol. 29 (10): 1649-1672.

Bajracharya, D. 1983. "Fuel, Food or Forest? Dilemmas in a Nepali Village." World Development. 11(2): 1057-74.

Baland, J.M. and J. P. Platteau.1996. Halting Degradation of Natural Resources: Is there a Role for Rural Communities? Oxford: Clarendon Press.

Baral, J. C. 2002. "Who Should Control the Forests of Nepal?" Case study for Mountain Forum E-consultation for UNEP / Bishkek Global Mountain Summit. (http:// www.mtnforum.org).

Bhattarai, L. N. 2004. "Poverty Environment Linkages: A Study of Use and Management of Forest Resources in Mahabharat Tract, West Nepal". Unpublished Thesis (Jawaharlal Nehru University, New Delhi).

Ostrom, E. 1990. Governing the Commons: The evolution of institutions for collective action. New York: Cambridge University Press.

Thapa, G.B. and K.E. Weber. 1990. Managing Mountain Watershed: The Upper Pokhara Valley, Nepal. Bangkok: Asian Institute of Technology. 